This article is licensed under the Creative Commons Attribution-NonCommercial 4.0 International License (CC BY-NC) (http://www.karger.com/Services/OpenAccessLicense). Usage and distribution for commercial purposes requires written permission.

\title{
Longer Control of Nivolumab in Metastatic Renal Cell Carcinoma Patients with End-Stage Kidney Disease on Dialysis
}

\author{
Ryota Morinaga $^{a} \quad$ Takashi Kawahara $^{a, b} \quad$ Yasuhide Miyoshi $^{a}$ \\ Masahiro Yao ${ }^{\mathrm{b}}$ Hiroji Uemura ${ }^{\mathrm{a}}$ \\ aDepartments of Urology and Renal Transplantation, Yokohama City University Medical \\ Center, Yokohama, Japan; ${ }^{b}$ Department of Urology, Yokohama City University Graduate \\ School of Medicine, Yokohama, Japan
}

\section{Keywords}

Nivolumab · Dialysis · mRCC

\begin{abstract}
Introduction: Nivolumab has been introduced for metastatic renal cell carcinoma (mRCC) as a second-line therapy for years. However, despite widespread evidence of its utility, few reports have described the efficacy of nivolumab for MRCC patients on hemodialysis. Case Presentation: A 68-year-old man with a 20-year history of dialysis due to chronic glomerulotubular nephritis was referred to our department for bilateral renal tumors in 2015. In February 2015, contrast-enhanced CT revealed findings suggestive of RCC, so we performed right nephrectomy. The pathological diagnosis was clear cell carcinoma and papillary renal cell carcinoma. In July 2015, we consequently performed left nephrectomy, and the pathological diagnosis was metastatic RCC. In February 2016, because follow-up CT revealed a right adrenal tumor with time-dependent growth, sunitinib (25 mg/body) was introduced. In January 2017,
\end{abstract}




\section{Case Reports in Oncology}

Case Rep Oncol 2019;12:608-612

DOI: $10.1159 / 000501768$

2019 The Author(s). Published by S. Karger AG, Base www.karger.com/cro

Morinaga et al.: Longer Control of Nivolumab in Metastatic Renal Cell Carcinoma

Patients with End-Stage Kidney Disease on Dialysis

although sunitinib had controlled the adrenal metastasis for 9 courses (11 months), liver metastasis was observed, so nivolumab was introduced as a second-line chemotherapy in March 2017. Nivolumab was able to control the mRCC for 15 months (32 courses). While CT showed no metastatic sites except for the liver and adrenal glands, his general condition gradually decreased, and he died in October 2018. Conclusion: We herein report a patient with RCC on hemodialysis with long-term cancer control by nivolumab.

(C) 2019 The Author(s)

Published by S. Karger AG, Basel

\section{Introduction}

The incidence of renal cell carcinoma (RCC) in hemodialysis patient is higher than in nondialysis patients, reaching 1.5\% [1]. However, there is no established treatment for hemodialysis patients with RCC [2]. While some tyrosine kinase inhibitors (TKIs) have been used for metastatic RCC (mRCC) in patients with end-stage kidney disease at a reduced dose, no dosereduction evidence exists concerning immune-checkpoint inhibitors, such as ipilimumab and nivolumab, so all hemodialysis patients undergo full-dose treatment for mRCC. Regarding nivolumab, two cases have been reported concerning mRCC in patients receiving hemodialysis $[2,3]$.

We herein report a case of the long-term control of dialysis-related RCC using nivolumab.

\section{Case Presentation}

A 68-year-old man was referred to our hospital for the further examination of a right renal mass in November 2014. He had been received hemodialysis due to end-stage kidney dysfunction induced by chronic glomerulus nephritis since 1996. In February 2015, right nephrectomy was performed. A pathological examination showed clear cell carcinoma combined with papillary RCC in the cystic area, and the surgical margin was negative. During follow-up, a left right tumor was revealed by scheduled computed tomography (CT), so left nephrectomy was performed in July 2015. The pathological diagnosis was metastatic RCC. In October 2015, follow-up CT detected an enlarged right adrenal mass (131.9 mm diameter), so sunitinib (25 mg) was administered. He received sunitinib treatment for 9 courses but discontinued it due to liver metastasis on January 2017. He then received nivolumab as a second-line treatment from March 2017. Nivolumab was administered at a full dose and continued for to 32 courses until August 2018 (Fig. 1). The tumor size was controlled as stable disease (SD), but he died on October 2018.

\section{Discussion}

Since it was first reported by Dunill et al. in 1977, the incidence of RCC has been shown to be higher in dialysis patients than in non-dialysis patients, especially for young men $[4,5]$. The mean duration from dialysis installation to RCC development is 8 to 10 years, but some patients develop RCC after about 5 years. 
For advanced or recurrent mRCC, nivolumab has been used as a second-line treatment in Japan. In 2018, combination therapy between ipilimumab and nivolumab was introduced as a first-line treatment for mRCC. The CheckMate-025 study revealed that nivolumab resulted in an overall survival of 25.0 months, compared to 19.6 months with standard treatment ( $p=$ $0.002)[6,7]$. However, no previous studies have included patients receiving dialysis.

There have been few reports describing TKI or immune-check point inhibitor treatment [8-10]. While the ideal dose of TKI for end-stage kidney disease has not been established, in most cases, some degree of dose reduction is applied. For nivolumab treatment, only two cases have been reported [2,3], and all cases - including our own - received nivolumab without dose reduction (Table 1 ).

Carlo et al. reported that nivolumab was not affected by the renal function or dialysis, so dose reduction was not necessary [2]. All cases showed efficacy and were able to receive fulldose treatment of nivolumab $[2,3,11]$. Our patient was able to continue nivolumab treatment for 15 months, and radiographic progression was not detected, although the patient ultimately died 17 months after installation of nivolumab. Pre-nivolumab treatment in our case consisted of only sunitinib, whereas other previous cases used 3 and 6 regimens before nivolumab treatment (Table 1).

We herein report a fourth case of nivolumab treatment for RCC in a patient receiving hemodialysis.

\section{Availability of Data and Material}

Due to ethical restrictions, the raw data underlying this paper are available upon request to the corresponding author.

\section{Statement of Ethics}

Written informed consent was obtained from the patient. A copy of the written consent form is available for review from the Editor-in-Chief of this journal.

\section{Disclosure Statement}

The authors declare no conflicts of interest.

\section{References}

1 Kondo T, Sasa N, Yamada H, Takagi T, Iizuka J, Kobayashi H, et al. Acquired cystic disease-associated renal cell carcinoma is the most common subtype in long-term dialyzed patients: central pathology results according to the 2016 WHO classification in a multi-institutional study. Pathol Int. 2018 0ct;68(10):543-9.

2 Carlo MI, Feldman DR. Response to Nivolumab in a Patient With Metastatic Clear Cell Renal Cell Carcinoma and End-stage Renal Disease on Dialysis. Eur Urol. 2016 Dec;70(6):1082-3. 
3 Tabei T, Natsume I, Kobayashi K. Successful treatment of metastatic clear cell carcinoma with nivolumab in a patient receiving dialysis treatment. Int J Urol. 2017 Sep;24(9):708-10.

4 Dunnill MS, Millard PR, Oliver D. Acquired cystic disease of the kidneys: a hazard of long-term intermittent maintenance haemodialysis. J Clin Pathol. 1977 Sep;30(9):868-77.

5 Ohtaka M, Kawahara T, Ishiguro Y, Sharma M, Yao M, Miyamoto H, et al. Expression of receptor activator of nuclear factor kappa B ligand in bladder cancer. Int J Urol. 2018 Oct;25(10):901-2.

6 Motzer RJ, Tannir NM, McDermott DF, Arén Frontera O, Melichar B, Choueiri TK, et al.; CheckMate 214 Investigators. Nivolumab plus Ipilimumab versus Sunitinib in Advanced Renal-Cell Carcinoma. N Engl J Med. 2018 Apr;378(14):1277-90.

7 Motzer RJ, Escudier B, McDermott DF, George S, Hammers HJ, Srinivas S, et al.; CheckMate 025 Investigators. Nivolumab versus Everolimus in Advanced Renal-Cell Carcinoma. N Engl J Med. 2015 Nov;373(19):1803-13.

8 Josephs D, Hutson TE, Cowey CL, Pickering LM, Larkin JM, Gore ME, et al. Efficacy and toxicity of sunitinib in patients with metastatic renal cell carcinoma with severe renal impairment or on haemodialysis. BJU Int. 2011 Oct;108(8):1279-83.

9 Shetty AV, Matrana MR, Atkinson BJ, Flaherty AL, Jonasch E, Tannir NM. Outcomes of patients with metastatic renal cell carcinoma and end-stage renal disease receiving dialysis and targeted therapies: a single institution experience. Clin Genitourin Cancer. 2014 Oct;12(5):348-53.

10 Guida A, Masini C, Milella M, Di Lorenzo G, Santoni M, Prati V, et al. Retrospective analysis on safety and efficacy of everolimus in treatment of metastatic renal cancer patients receiving dialysis. Future Oncol. 2015;11(23):3159-66.

11 Ansari J, Ali M, Farrag A, Ali AM, Alhamad A. Efficacy of Nivolumab in a Patient with Metastatic Renal Cell Carcinoma and End-Stage Renal Disease on Dialysis: Case Report and Literature Review. Case Reports Immunol. 2018 Jun;2018:1623957.

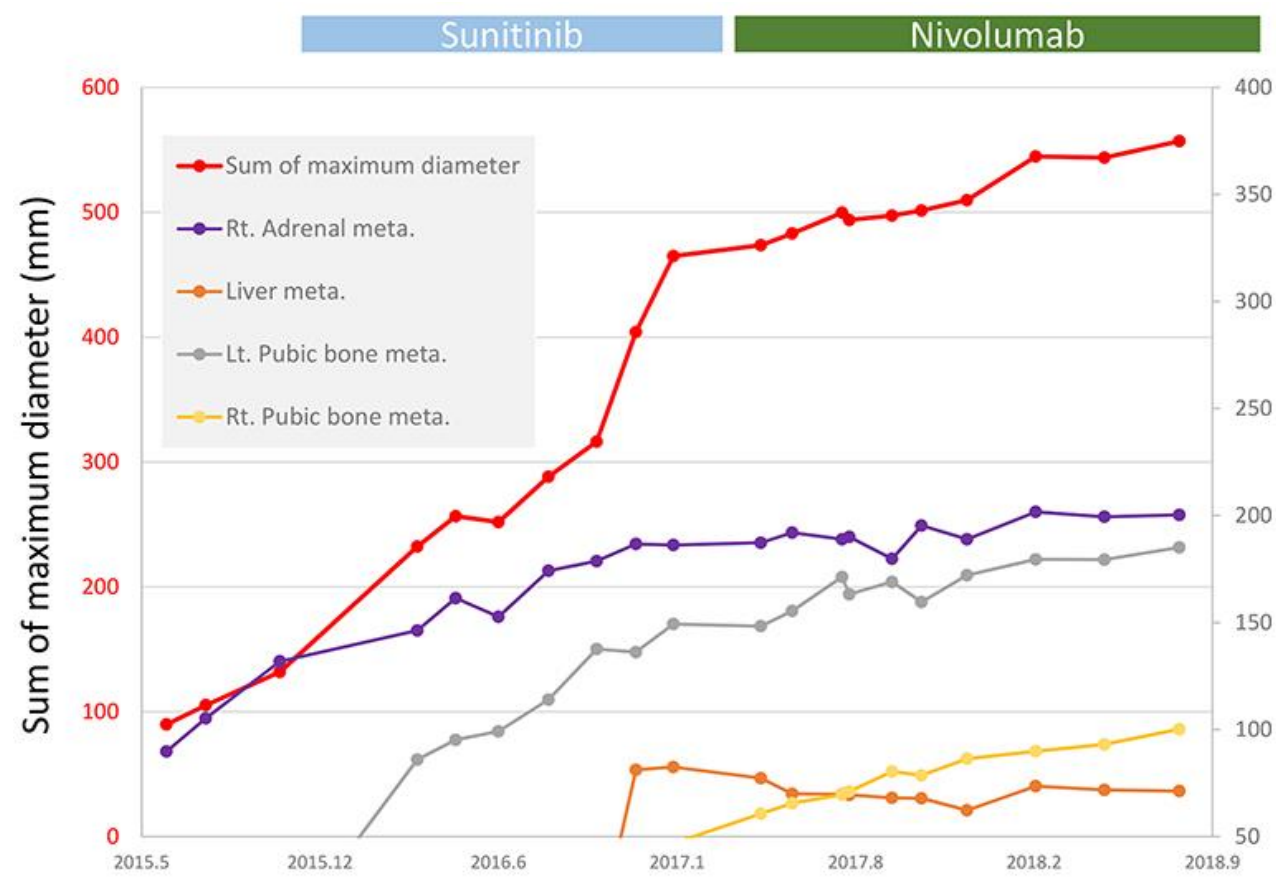

Fig. 1. Clinical courses. 


\section{Case Reports in Oncology}

Morinaga et al.: Longer Control of Nivolumab in Metastatic Renal Cell Carcinoma

Patients with End-Stage Kidney Disease on Dialysis

Table 1. Nivolumab treatment in mRCC patients that underwent dialysis

\begin{tabular}{lllllll}
\hline & $\begin{array}{l}\text { Age, } \\
\text { years }\end{array}$ & Gender & Pathology & TNM stage & Prior treatment & $\begin{array}{l}\text { Time from } \\
\text { diagnosis to } \\
\text { nivolumab }\end{array}$ \\
\hline $\begin{array}{l}\text { Carlo } \\
\text { et al. }\end{array}$ & 77 & Male & Clear cell & pT2aNxM0 & $\begin{array}{l}\text { Partial nephrectomy, radical nephrectomy, } \\
\text { pazopanib, everolimus, sorafenib }\end{array}$ & $\begin{array}{l}\text { 2 years, } \\
10 \text { months }\end{array}$ \\
$\begin{array}{l}\text { Tabei } \\
\text { et al. }\end{array}$ & 49 & Male & Clear cell & pT1bNxM1 & $\begin{array}{l}\text { Radical nephrectomy, Interferon alpha, sorafenib, } \\
\text { everolimus, sunitinib, axitinib, pazopanib }\end{array}$ & $\begin{array}{l}8 \text { years, } \\
11 \text { months }\end{array}$ \\
$\begin{array}{l}\text { Current } \\
\text { case }\end{array}$ & 68 & Male & $\begin{array}{l}\text { Clear cell + } \\
\text { papillary }\end{array}$ & pT1aN1M0 & Radical nephrectomy, sunitinib & 2 years, \\
\hline
\end{tabular}

